Historic, Archive Document

Do not assume content reflects current scientific knowledge, policies, or practices. 



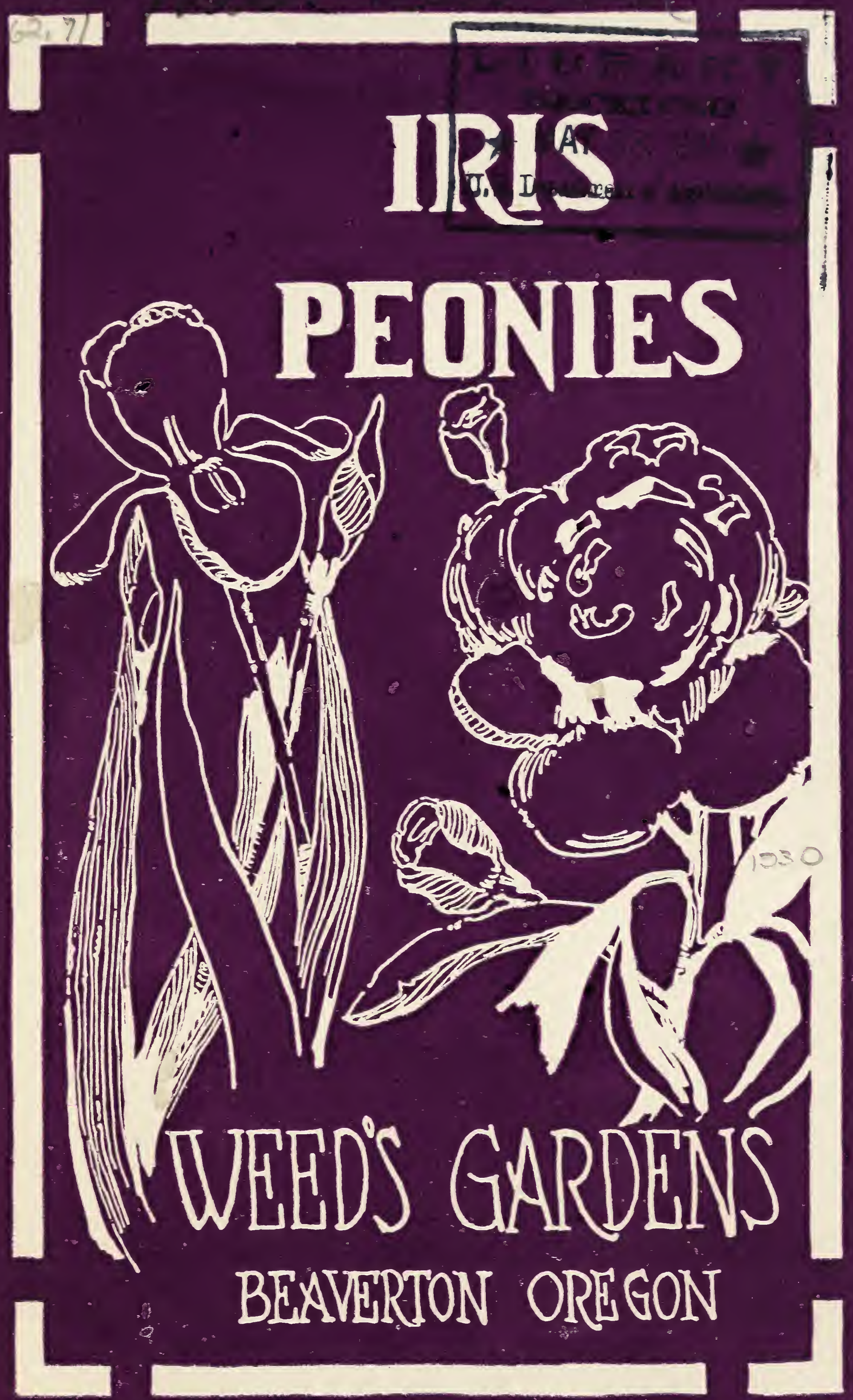





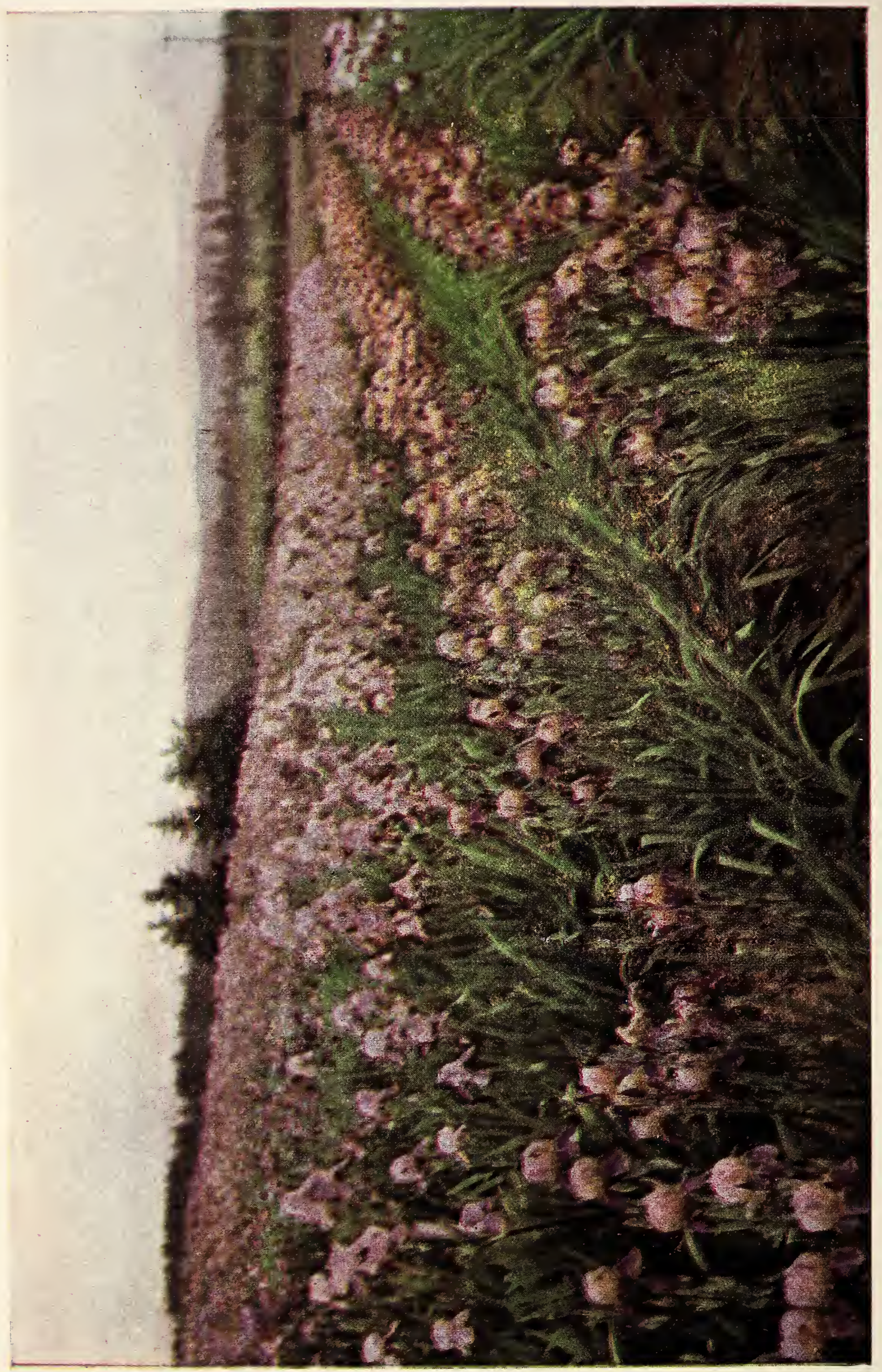

ท

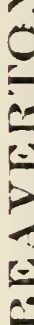

A

1

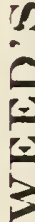

?

12

岂

.

0

政

:

6 in

o

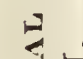

H 


\title{
A Coatalng
}

- OF THE -

\section{NEWEST AND BEST}

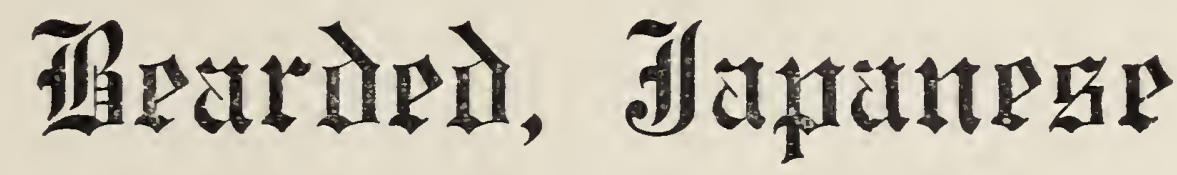

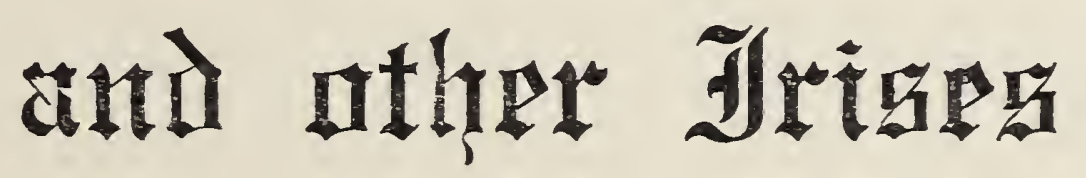

\author{
ALSO OF
}

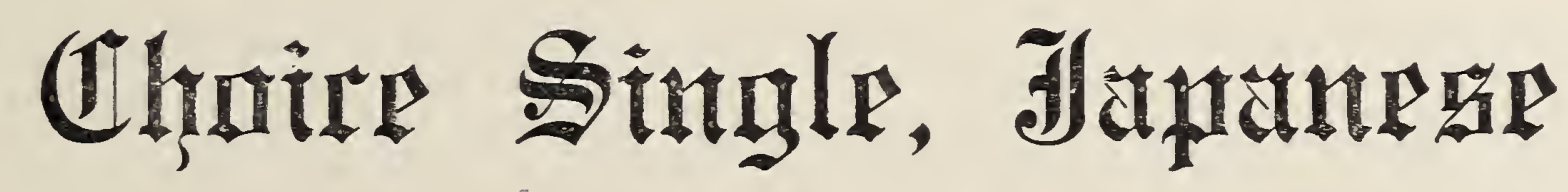

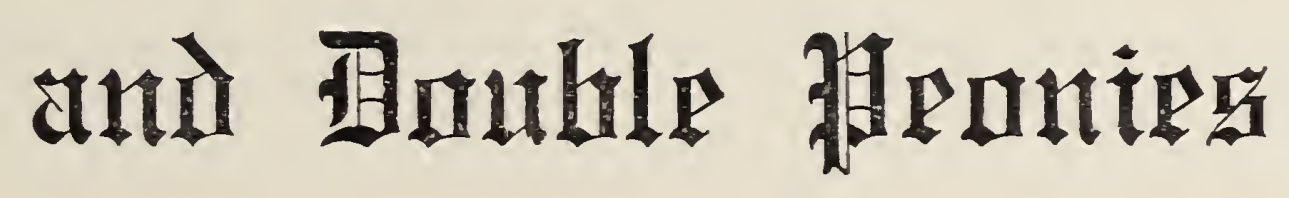

\section{III}

\section{WEED'S GARDENS}

BEAVERTON, OREGON 


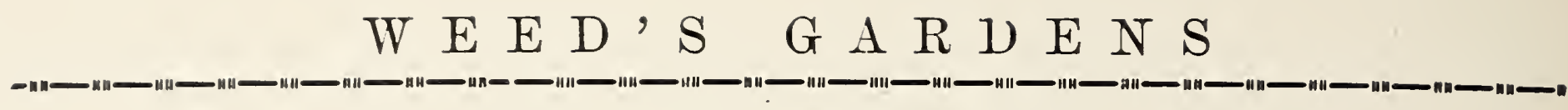

\section{FFOM OUR CUSTOMERS.}

\section{I r i s.}

"I never received a finer lot of Iris roots from anyone, and I now have more than four hundred varieties." .

Frances Lawton, Thornton, Rhode Island.

"I must comment on your plants. They are the largest and finest I have ever seen."

Wesley I. Coddington,

Martinsville, New Jersey.

"I sent you a trial order last year and your plants were fine - much lager than those of other growers."

Walter H. Kiessig,

Davenport, Ia.

"All the plants were very nice ones."

Edith Childs, Chicago, Illinois.

"I certainly was pleased with my Iris last spring."

\section{Edward E. Knox,}

Cincinnati, Ohio.

"I would like to inform you how pleased I was with the Iris. I hardly expected to have more than a bloom or two this year, but to my surprise there were more than forty. They are perfectly beautiful colors. I wish to thank you for making this selection and to tell you how much I enjoy them."”

Frank E. Robson, Attorney for Michigan Central Railway, Detroit.

"The shipment I received from you last year was by far the nicest stock of all that I purchased. Practically every plant bloomed despite the late planting."

Mary E. Thomas, Wichita, Kans.

\section{P e o n i e s.}

"The peonies were splendid and arrived in perfect condition. The roots were large and the buds big and fat. There may be some flowers next year."

E. O. Essig, Berkeley, Califoreina.

"Peonies are O. K. and came thru in fine shape."

\section{F. Wassenberg,} Van Wert, Ohio.

"My recent order of peonies came through in fine shape and were entirely satisfactory in every respect."

Mrs. M. A. Buchan, Palo Alto, California:

"The peony roots sent me were cerlainly fine and I expect to have some garod blooms from them."

B. G. Huse, Lorain, Ohio. 


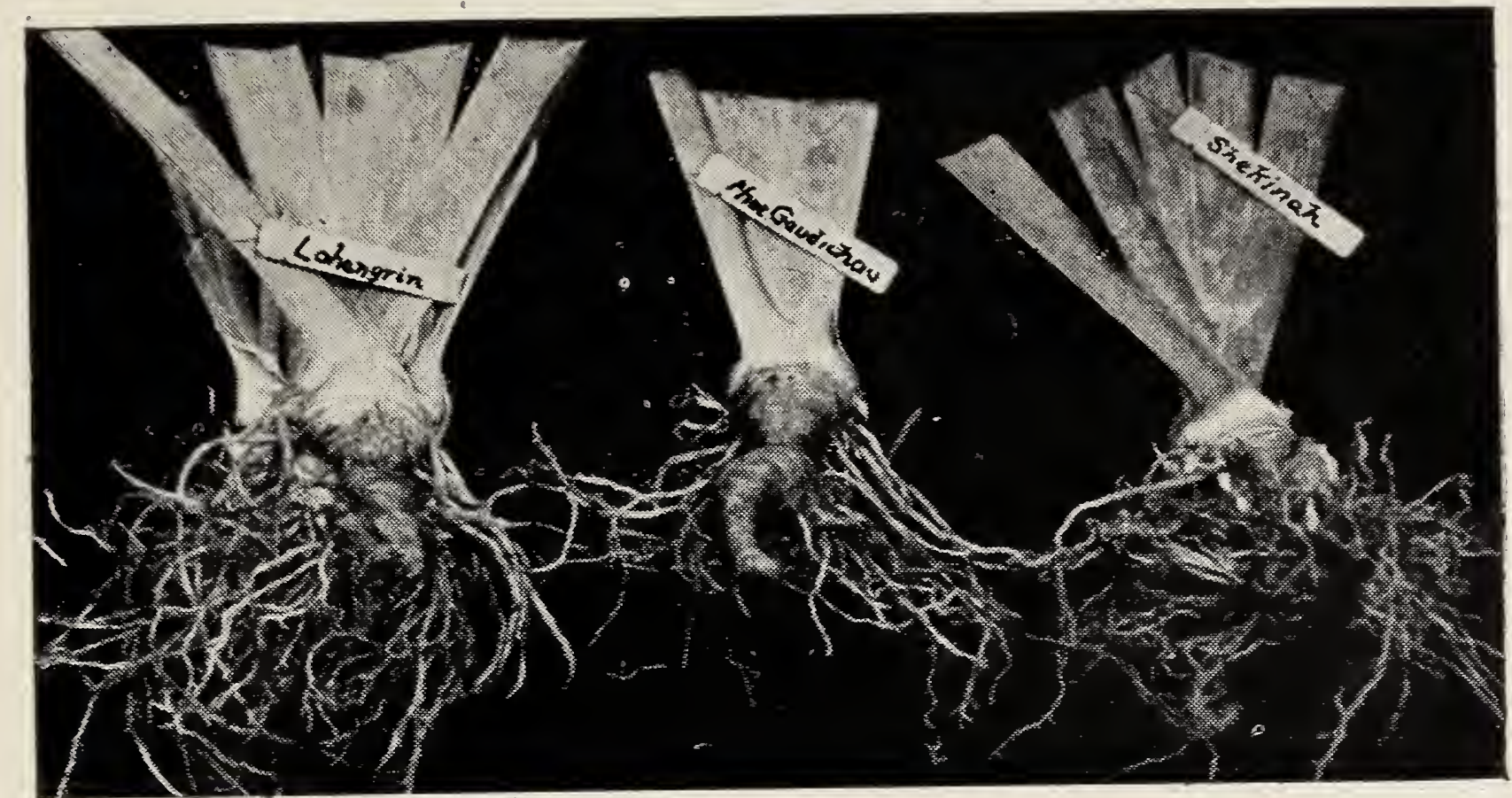

OREGON GROWN PLANTS.

\section{INFORMATION REGARDING IRIS.}

No orders filled for less than one dollar. Cash with order.

With such a large list of varieties, we give but short descriptions. The letter S. refers to the standards or upright petals and the letter F. refers to the falls or horizontal petals.

We prepay postage on retail orders and ship without delay.

Do not plant the iris too deep; rhizome should show above ground.

We have a large trade built on a reputation for furnishing fine, large rhizomes that bloom the first year. Anyone receiving a plant with which they are not fully satisfied, will receive their money back upon returning the rhizone.

If you have never given us a trial order, we trust that you will do so this year in order to know the quality of our rhizomes. Compare our prices and compare our plants; we know you will be satisfied.

We catalog but a few varieties receiving a garden rating below 80 ; the exceptonis we consider should rate much higher. Any grower who does not publish the rating, in our opinion. is simply ashamed to have it known as to what a lot of "junk" he grows. 


\section{INTRODUCTION.}

Weed's Gardens have been estaplished as a nursery since 1910, when specialization in peonies had its beginning. Specialization in iris began in 1914 , at which time the leading varieties then in existence were obtaned. Later introductions were added from year to year, until now we possess one of the best selections in the country. Our trade in iris and peonies has so increased from year to year that two years ago we decided to retire from the general nursery trade in "order to devote: full time to iris and peonies. With this change has come the new name of "Weed's Gardens", an old concern under a new name.

We are located on the Canyon Road six miles west from Portland, and one mile east from Beaverton. This road has been regraded and is the main highway to the coast. Visitors are welcome at all times, for eren during the winter months we can show bloom of the delightful Angustifolia, our winter bloomer. By the time this variety is through blooming in April, the early dwarfs are showing, followed by the intermediates. These are followed by the tall bearded varieties and finally the delightful Japanese.

Our peonies make a grand showing of bloom during the month of June, at which time we coilduct a peony show in the basement of our new residence. Visitors are invited at any time, but specially urged to visit us during May and June. Orders are then booked for delivery at the proper planting time.

We also furnish Decoration Day flowers at about one-fourth the price asked for them at the down-town stores. If the season is early, we have thousands of peony blooms for such purpose, while if the season is late, we have the iris blooms. An added advantage is that our flowers are fresh-picked while you wait.

During the blooming season. we furnish flowers for weddings, entertainments, and other social affairs where decorations are required.

We will be pleased to send a copy of this catalog to any of your friends upon request.

WEED'S GARDENS,

Beaverton, Oregon. 


\section{TALL BEARDED IRIS.}

These are the iris most generally known and by far the most popular. From May 15 to June 10 they form a riot of color in an iris garden:

AARESHORST. S. white, flushed carmine. F. deep plum violet.

AEGIR. S. white, flushed carmine. F. bright carmine violet.

82 AFTERGLOW. Grayish-lavender. Very prolific in bloom.

ALABASTER. A very fine white flower.

87 ALCAZAR. S. light mauve. F. cotinga purple. This is a very striking flower. In fact it is the best of the cheaper iris.

88 ALIQUIPPA. Pale massicott yellow. Very free flowering. 1.00

84 ALLIES. S. deep violet rose. F. velvety red purple. 4.00

85 ALLURE. S. irridescent pink, flushed yellow. F. pink and lavender blue, flushed gold. This variety sold for $\$ 25$ last year. 10.00

85 ALVARADO. Deep rich purple, tall and vigorous. 1.00

81 AMADOR. A pink bicolor similar to Leverrier, but stronger. $\quad .75$

91 AMBASSADEUR. S. smoky violet. F. reddish violet. Very large. .50

88 AMBER. A very fine pure deep yellow. Excellent blooms. $\quad .75$

AMERIND. Metalic bronze, named from the native Indians. $\quad 1.00$

82 ANDREE AUTISSIER. Large flowers of pale lilac blue. 75

84 ANNE BULLEN. A fine dark velvet bicolor.

85 ANN PAGE. Uniform pale blue. Good flower. 25

ANTARES. S. yellow. F. pure white, dotted ageratum blue. $\quad 5.00$

88 APACHE. S. coppery red. F. dark crimson brown. 2.00

81 APHRODITE. Flower is dark purplish pink, and very distinct. 1.00 APRICOT. Large flower of apricot coloring. $\quad .50$

ARGENTINA. A tall lovely white. Very beautiful.

ARGOS. S. dauphin"s blue. F. velvety petunia violet. 5.00

83 ARGYNNIS. S. yellow. F. chestnut brown. Lovely. .50

81 ARIADNE. S. silvery blue, veined brown. F. deeper shade. $\quad .50$

84 ARLINGTON. Large flowers of rich red purple tone. 35

ARIMAND CLAVAUD. Fine yellow, dotted and veined violet. $\quad .50$

ARZANI. A fine glowing pink and red flower. $\quad 5.00$

84 ASA. S. cream yellow. F. white, on yellow ground. 5.00

88 ASIA. Soft lavender, which when fully opened is magnificent. $\quad 1.25$

89 ASPHODEL. A beautiful light lavender. One of the finest. 2.00

83 ATHENE. A very fine creamy white of good size. 1.03

AUBURN. S. rose purple. F warm crimson. Beautiful flower. 4.00

AURIFERO. A beautiful lavender of two shades. 2.00

81 AVALON. Pinkish lavender. A very tall flower. 1.0 J

AVATAR. Heliotrope grey. F. pansy violet in color. 3.00

84 AZRAEL. S. ageratum violet. F. petunia violet. 1.50

84 AZULADO. Large flowers of lustrous, pearl gray blue. $\quad .50$ 
AZYIADE. S. sky blue. F. soft bluish mauve. Distinctive. $\quad 4.00$ 82 BALBOA. A tall, bright red violet bicolor. $\quad .50$

82 BALDER. S. Lavender: F. velvety maroon-purple. $4 \mathrm{ft} . \quad \mathbf{5 0}$ BALDWIN. A manganese violet self of large size on 40 inch stem. 7.50 89 BALLERINE. S. light violet-blue; F. deeper. 4 ft.

85 BANDOLLERO. A distinctive light blue color. $\quad .75$

BATULUS. S. bright purple-rose. F. rose crimson. 1.50

82 BEAU IDEAL. White, distinctly edged petunia violet. Large. .50

80 BELISAIRE. S. light tan. F. crimson madder. Exquisite. 2.50

BELLORIO. A graceful flower of lavender grey. Early. $\quad 1.00$

BLUE VELVET. The sensation of last year. A clear velvety blue. 40.00 BONITA. A very fine yellow flower, long in bloom. 4.00

82 BRANDYWINE. Pale silvery azure blue. Very good. $\quad .25$

BRAVURA. Deep rosy lilac flowers of great beauty. 1.50

90 BRUNO. S. fawn. F. rich red purple. An attractive flower. 4.00 BUTO. Rich royal purple, falls almost black. $\quad 5.00$

80 B. Y. MORRISON. S. lavender-violet; F. anthracnose violet. $\quad .35$

CAMELIARD. Soft yellow in color overlaid with wine. 10.00

91 CANDLELIGHT. A pinkish bluff on the order of Afterglow. $\quad 5.00$

84 CANOPUS. An improved Alcazar, being à Dominion seedling. $\quad .50$

CANYON MISTS. A delightful soft mauve self. Very outstanding. 1.00

90 CARDINAL. S. lavender. F. dark red purple. Wonderful bloom. 5.00

83 CAROLINE E. STRINGER. A celicate shade of rose. 230

CASSENDRA PERRY. S. volet rose. F. crimson. Large. 1.00

CASSIOPEE VILMORIN. S. smoky bronze. F. blue and penciled. 4.00

83 CATERINA. Bluish-lavender self of great beauty. .25

86 CENTURION. S. clear deep violet. F. deep velvety Durple. 3.00

CHABE2. S. lobelia blue and ochre; F. deep purple.

$86 \mathrm{CHALICE}$. Best of the low priced yellows. .50

85 CHASSEUR. A clear straw yellow growing very tall. $\quad .50$

81 CHLORINDA. Very lárge, soft amber yellow. $\quad 1.50$

CHURCHMOUSE. Hay's brown self. Wonderful new color. 5.00

CINDERELLA. S. pearl, shading to Fluff. F. light purple. 1.00

CINNABAR. S. violet purple. F. cotinga purple. Very fine. 5.00

85 CITRONELLA. S. clear yellow. F. ruddy brown. Different. 1.00

86 CLARIDAD. An early clear lavender blue. Beautiful. 1.00

80 CLUNY. A lilac blue self. Large flowers on tall stems. .25

82 COLIAS. Light yellow self. $\quad .35$

CONCHITA. S. pale bronze. F. lined red. Striking flower. 1.50

85 CONCHOBAR. Rich purple with reddish tinge. Very fine. 4.00

83 CONQUISTADOR. Deep mauve to light violet. Very tall. .50 COOLEY SURPRISE. Soft heliotrope shade. S. lighter. 42 inches 15.00 
80 CORNAULT. Fine coppery red flowers.

86. CORONADO. A mettalic blending of lavender and red purple.

83 CRIMSON GLOW. Similar to Ed. Michel, but better. Violet purple. 1.00

85 CRUSADER. A large blue-violet self.

83 CYGNET. A fine ivory-white on tall stems.

81 CYPRIANA. Two shades of violet. Beautiful blending. .25

82 DAMOZEL. A ruffled white plicata. .35

81 DAPHNE. S. clear white. F. true blue. Attractive combination. 1.00 DAUNTLESS. Probably the finest red iris ever offered. $\quad 30.00$

DEBUTANTE. Pink lavender flushed standards. Tinted bicolor. .75

80 DELICATISSIMA. Hortense violet to amparo purple. .25

83 DELIGEIT. A prire white plicata of good size. .25

91 DOLLY MADISCN. A very pretty flower of mauvette and lilac.

Without doubt the best iris ot its color.

DOLORES. S. margined red-violet; F, deeper.

DON QUIXOTE. S. deep lavender and yeilow. F. hyssop violet. 1.50

DOROTHY DIETZ. S. chicory blue. F. pansy violet. Very fine. 7.50

34 DREAM. A typical pink, being a lilac self. Good grower. 25

82 DRYADE. S. clear metallic blue. F. violet crimson. 2.00

87 DUIEE OF BEDFORD. S. deep violet. F. deeper violet purple. 2.00

DUKE OF YORK. S. mauve blue. F. same, almost a self.

DULCINEA. S. lavender. F. violet blue, lavender margins. $\quad 1.00$

83 EDEN PHILPOTTS. Uniform dark lavender blue. Very pretty. $\quad .50$

81 EDOUARD MICHEL. 'Rood's violet to dark purple self.

87 EL CAPITAN. A manganese violet bicolor of great beauty. Large 1.00

81 ELBERON. S. red purple. F. deeper. $\quad .50$

84 EMBER. Violet red. A very beautiful flower. 2.00

82 ENSIGN. S. 'lobelia violet; F. petunia violet. ' .25

86 ESPLENDIDO. A large red bicolor. Splendid effect.

ETOILE DU MATIN. Sulpliur yellow, the S. dotted brown. F. blue. 5.00

87 EVADNE S. rosy violet. F. deeper. A good rose red. 1.00

EVENTIDE. A distinctive slaty lavender. $\quad 3.00$

FENTON. Lavender blue of fine quality.

81 FIDELIO. S. metallic blue. F. clear violet. Large fiowers. $\quad 2.00$

FIREFALL. One of the brightest red irises of the garden. $\quad 4.00$

FISMES. S. cream with falls soft reddish lavender $\quad 1.50$

FLAMINGO. General flower effect is a bright rosy red. 1.50

80 FLAMIMENSCHWERT. S. clear yellow. F. maroon bordered yellow. .50

84 FOLKWANG. S. white. F. claret red. Very beautiful. 75

FORTUNA. S. clear amber yellow. F. lined red brown. 3.03

FRA ANGELICO. S. light bronze gòld. F. deeper. A beauty. $\quad 5.00$

85 FRIEDA MOHR. A wonderful pink lavender. 42 inches high. 5.00

87 GABRIEL. S. light clear steel blue. F. violet blue. 5.00 
82 GAVIOTA. A fine creamy white plicata. F. edged yellow.

GAY HUZZAR. S. lemon chrome. F. veliety ox-blood red. 4.00

88 GEORGE J. TRIBOLET. S. violet. F. velvety red purple. Early. 1.50

85 GEORGE YELD. S. bright apricot shaded rose. F. rose crimson. 1.50

83 GEORGIA. Uniform cattleya rose.

90 GERMAINE PERTHUIS. S. violet purple. F. Bishop's violet. 2.50

GLADYS ROBERTS. Large flowers of rosy violet. Early.

86 GLAMOUR. S. heliotrope tinged ochre yellow. F. violet. 2.50

GLORIAE. S. clear blue. F. bluish violet. Large flowers. 2.00

86 GLOWING EMBERS. S. cinnamon drab. F. pansy violet. Good. 2.00

82 GNOME. Lilac to rose, almost a self. Quite early.

GOLDEN GLORY. A new golden yellow of great promise. 2.00

81 GOLDEN PROMISE. Another beautiful yellow on good stems. $\quad .75$

87 GOLD IMPERIAL. Crome yellow throughout. Well-rated. 50

87 GRACE STURTEVANT. Dark reddish brown and violet carmine. 20.00

GREINADIER. Large velvety violet flowers. Very tall stalks. $\quad 3.00$

GRISETTE. S. walnut brown, the F. being slightly lighter. $\quad 4.00$

GROUSMAN RED. Brilliant cardinal tone. Extremely attractive. 5.00

81 HALO. S. lavender blue. F. violet blue. Pleasing effect. 35

$82 \mathrm{HARMONY}$. This iris is a deep rich violet purple self.

83 HARRIET PRESBY. An exceedingly tall petunia violet.

HAVAMAL. S. cream, flushed lilac. F. violet blue, border cream. 4.00

81 HERMIONE. This is a large flowering purple bicolor. $\quad .50$

82 HESPERIA. A maroon-purple blend of great beauty.

87 HIDALGO. A large lavender self. $\quad 1.00$

HIGH TIDE. See page seventeen. $\quad 10.00$

80 HIPPOLYTA. A pallida of pleasing mauve. $\quad .50$

HOMER C. Lilac pink with brown reticulations. Very fine. $\quad 4.00$

84 IMPERATOR. S. violet; F. reddish violet.

IMPRESSARIO. A new red purple. Very good. $\mathbf{5 . 0 0}$

ION. S. Bradley's violet. F. velvety blackish blue violet. 25.00

80 IRIS KING. S. old gold; F. velvety, crimson maroon'

84 ISOLINE. Chinese violet to russet. Very pretty, but small.

ISTRIA. S. white. F. greenish. An early and tine flower. $\quad-1.00$

80 JACINTO. S. light lobelia violet. F. ageratum vinlet. Fine. $\quad .50$

JACKROSE. Resembling a Tack Rose, hence the name. $\quad 10.00$

83 JACQUELINE GUILLOT. Very large silvery blue fiowers. $\quad 1.00$

JANE WILLIAMSON. S. bright vinaceous lilac. F. deeper. $\quad \mathbf{5 . 0 0}$

81 JEAN CHEVEREAU. S. cream, shaded bluff. F. white, dotted brown. .50

JUBILEE. S. bluff tinted soft pink. F. bluff, edges copper. 2.00

85 JULIA MARLOWE. A marvellous glowing pink and red. Tall. 1.50

81 JUNIATA. Mauve to manganese violet. 25

82 KASHMIRIANA. White, slightly washed lavender.

KAREN. A very deep rich red purple variety. 1.00

KATHERINE McFARLAND. S. mulberry purple. F. rich purple. 5.00

84 KESTREL. Blending of rich lobelia and velvet, violet tones. 4.00

83 KING KARL. A large creamy white flower, sanded lavender rose. 2.00 
KLAMATH. See page seventeen.

LA BOHEMIENNE. Deep heibore red flushed with bronze. Good. 5.00

87 LABOR. Violet helictrope, almost a se!f. Atracts attention. $\quad 5.00$

LADY BOUNTIFUL. Seedling of Alcazar, but a cléarer blue. 1.00

82 LADY FOSTER. Lavender-violet. Very- large and pretty. 35

83 LADY SACKVILLE. S. silvery blue. F. rich violet purple. 3.00

LA FAVORITE. A large, fine flower of uniform biue purple. $\quad 1.00$

LE CORREGE. S. bronze suffused violet. F. rich wine-red. 7.50

88 LE GRANDE FERRE. S. greyish fawn. F. vinous rose. 1.00

88 LENT WILLIAMSOI. S. lavender violet. F. pansy violet. Early. .35

LENZ-CHNEE. Fure white, fiushed lavender. Fine flower. , 7.50

88 LEONATO. A lavender flower of exceptional beauty. 48 inches. 1.00

\&2 LEVERRIER. S. mauve. F. velvety clear rich pansy violet. $\quad .75$

83 LONA. Soft bluff. sanded purple. Unusual blending. 2.00

:5 LURD LAMBOURNE. S. Rose-fawn; F. Chinese violet. .75

88 LORD OF JUNE. Chicory blue and lavender-violet. 50

LOS ANGELES. Great white fiowers of fine substance. 12.50

81 LOUIS BEL. S. velvety pansy violet. F. blackish violet. 2.00

LUSTRE. A violet purple which produces a red effect in mass. $\quad \mathbf{5 . 0 0}$

MAGENTA. Deep amethyst viclet, a new color for iris. $\quad 15.00$

85 MAGNIFICA. S. violet blue on white. F. reddish violet. .50

79 MAGNIFICENT. Large purple of heavy substance. 1.00

88 MAJESTIC. S. light lavender; F. raisin purple. $: 1.50$

83 MARGERY. S. wistaria violet; F. Bradley's violet. .35

MARQUISETTE. Shrimp pink, an entirely new color for iris. 6.00

81 MARSOUIN. S. Pale violet. F. violet purple. 2.50

81 MARSH MARIGOLD. S. golden yellow. F. deep purple brown. .50

90 MARY BARNETT. Beautiful light lavender, finest of its class. $\mathbf{5 . 0 0}$

85 MARY GIBSON. S. light bronze, old rose overlaid. F. old rose. 1.50.

81 MARY ORTH. A bicolor of beautiful blue violet .35

81 MAY SADLER. S. violet blue. F. madder crimson, bronze beard. $\mathbf{5 . 0 0}$

MELCHIOR. S. bronzy violet. F. velvety crimson purple. 25.00

83 MESTOR. S. broad light violet blue. F. Rich violet purple. $\quad 1.00$ MESSALINE. S. pale gold. F. red. A very fine iris. $\mathbf{7 . 5 0}$

90 MICHELINE CHARRAIRE. Pure white with golden reticulations. 4.00 MIDGARD. Yellow deeply flushed with rose pink. Beautiful. 6.00

81 MIDWEST. A deed pink plicata. Short stems. .25

86 MILDRED PRESBY. S. pale yellow; F. velvety violet. : 1.00

80 MILKY WAY. A lovely clear white. $\quad .25$

84 MLLE. SCHWARTZ. Large, purest mauve self. Free flowering. $\quad .50$

83 MME. CHERI. Ageratum violet, washed pink. Yellow undertone. .50

78 MME. CLAUDE MO $N E T$. Large blackish purple. MME. CHATENAY. S. rose ash color. F. old rose. 1.50

80 MME. CHOBAULT. S. pale yellow. F. veined pale brown. .25

86 MME. DURRAND. S. irridescent bluff. F. light amparo purple. 2.00

85 MME. HENRI CAYEUX. S. smoky reddish violet. F. dark crimson. 2.00

81 MME. VERNOUX. S. light blue. F. intense violet purple. 
87 MOA. S. violet. F. deep violet purple. Large and beautiful.

81 NONS. BRUN. Large flower of a fine brown tone. $\quad 1.00$

81 IVONTSERAT. S. dull lavender. F. livid purple shading. 1.00

84 MOONLIGHT. S. amber yellow. F. sulphur yellow. 1.50

91 MORNING SPLENDOR. S. petunia violet; $F$. raisin purple. 1.00

84 MOTHER OF PEARL. A large flower of bluish-lavender. $\quad .25$ MOUNT ROYAL. S. deep bluish violet. F. red pansy violet. $\quad 7.50$

79 IIRS. CHARLES PEARSON. Pale mauve with the F. deeper. $\quad .50$

MRS. CUTHBERTSON. S. rose, overlaid apricot. F. rosy crimson. 1.00

80 MRS. HETTY MATSON. S. purple bronze.F. rich crimson purple. $\quad .50$

83 MRS. H. F. BOWLES. S. soft brown. F. brilliant brick red. Unique. 1.50

79 MRS. MARION CRAN. A glorious shade of brilliant rose. 2.00

91 MRS. VALERIE WEST. S. lavender shot with bronze. F. crimson. 30.00

81 NANCY ORNE. A reddish blend of lilac shades. .25

NEBRASKA. An attractive apricot yellow. Very fine. $\quad 4.00$

NEWTONIA. See page seventeen. $\quad \mathbf{5 0 . 0 0}$

82 OCHRACEA. Old gold with center of F. violet. .50

82 ODAROLOC. Soft mauve to lobelia violet. A self color. 1.50

ODENVOGEL. S. bright citron yellow. F. purple violet. Good. 5.00

ODETTE OLIVET. A soft orchid pink, but as yet little known. 2.00

OLD GOLD. A very fine coppery blend. Attractive flower. $\quad 2.00$

84 OLIVE MURRELL. S. lavender rose. F. lavender bluc. 2.50

83 OLYIVIPUS. S. rose, overlaid bronze. F. madder crimson. Massive. 1.00

OMAHA. A wonderful deep vinous red. Striking iris. 5.00

83 OPERA. S. lilac red. F. purple violet. $\quad .50$

87 OPHEIIA. Pink, blended with orange, color of Ophelia rose. $\quad 4.00$

84 OREAD. Brilliant bronze and crimson. Large, fine texture. $\quad 5.00$

OREGON BEAUTY. See page seventeen. 50.00

OREGON GIANT. See page seventeen. $\quad 50.00$

ORION. S. Smoky violet. F. velvety blackish violet. Enormous. 4.00

84 PALEMON. General apricot effect.

80 PARC DE NEUILLY. Pleroma violet self. Rich coloring. .25

82 PEAU ROUGE. Copper and blood red. 1.50

89 PEERLESS. A very large flower giving effect of mahogany red. 7.50

82 PERLADONNA. Rich shade of "China blue."

83 PETREL. S. hortense violet. F. amethyst violet. $\quad .50$

90. PETRUCHIO. A much larger and finer Alcazar. Attractive. - 7.50

84 PHYLIIS BIISS. Pale rosy lavender. 25

90 PIONEER. S. rich red purple. F. glowing red purple. Magnificent 1.50

PLUMED INIGHT. White, veined and stippled pink. 1.50

90 PRINCESS BEATRICE. Self, between light and lavender-violet. .25

80 I'RONEUS. S. heliotrope blue. F. purple blue. Large flowers. 40U

82 PROSPIEO. S. Lavender; F. red-purple. Very fine.

95 PURISSIMA. The largest and fincst pute white introduced. 1203

PURPLE LACE. A rich blue purple, with a lacy throat. 1.50

PURPLE HAZE. A new French grey, overlaid with purple. 5.00 
88 QUEEN CATERINA. Large pale orchid colored self.

E2 RAJPUT. Bright violet on stems of 40 inches.

81 RAMELDO. Brownish petunia violet. Unusual.blend.

RAMONA. Petunia violet flushed brown.

REALM. Intense light blue seif of great beauty. $\quad 5.00$

EC RENE CAYEUX. A very large white bicolor. F. crimson violet. 2.00

82 REVERIE. S. colonial bluff. F. an unusual red. Late. 1.00

87 PEEINGAUPERLE. A beautiful soft rose flower. 1.00

83 RHEIN NIXE. S. white. F. pansy violet. .25

E2 RIALGAR. A modern variegata, mostly buttercup yellow. , 2.00

83 ROBERT WALLACE. Very rich dark violet and purple black. 2.00

89 ROMOLA. S. pale lilac tinged ivory. F. relvety red riolet. : 4.03

ROSADO. A beautiful soft clear pink. Tall and strong. 1.25

84 ROSALBA. Vinaceous mauve, nearly red. .35

83 ROSE MADDER. A beautiful flower in two shades of purple. 50

80.RUGAJO. Our own seedling. S. flesh pink. F. Rood's violet:

RUNSTEIN. S. olive lilac. F. deep velvety violet.

88 SAN FRANCISCO. A very large white, flowers edged lavender." 12.00

84 SAN GABRIEL. Large flowers of lustrous lavender. .50

SAN LUIS REY. A beautiful flower. A larger, finer Opera. $\quad 4.00$

89 SANTA BARBARA. Fure lavender blue. Finest of its color. $\quad 1.50$

SENORITA. Pastel shades, pale lavender overlaid yellow. 2.00

SENSATION. A wonderful corn-flower blue. Well named. 5.00

84 SHEKINAH. Pinard shading to empire yellow. $\quad .50$

SIKH. An iris of the Bruno type, but is more copper in tone. $\quad 10.00$

SILVER QUEEN. S. silver white. F. overlaid azure blue. 2.0J

81 SILVERADO. S. silvered larender. F. plumbago blue.

sO SINDIKHA. Deep lavender and violet. Tigorous grower. 35

81 SIMMONE VAISSIERE. A large fine blue of Oriflamme order. 1.00

¿4 SIR GALAHAD. A fine maure and pansy riolet colored flower. 2.00

gO SIR MICHAEL. S. clear larender blue. F. rich deep purple. 18.00

SKITCHEWAWG. Chinese violet to russet. Greatly improved. 5.C0

92 SOLEDAD. Amber yellow of clear tone. Very early. $: 5$

85 SOLFERINO. A lilac red self of great interest. Large. $\quad 7.50$

SOPHRONIA. A pure white flower of fine substance. 2.50

sO SOUV. LOETITIA MICHAUD. Lobelia blue, large and beautiful. 2.00

88 SOUV. MME. GAUDICHAU. Bradley's riolet. F. blackish purple. .50

82 STEEPWAY. S. fawn; F. rosy mauve. 35

STIPPLES. White with definite clear cut stipples on falls. 3.00

SUNLIGET. A very large clear yellow, quite nutstanding. $\quad 2 \mathrm{C} .00$

86 SUSAN BIISS. Uniform soft pink. Free flotrering. .50

82 SUZANNE AUTISSIER. S. clear analine blue. F. purple violet. .75

$\varepsilon 4$ SW $\triangle$ II. S. bluish-violet; F. rich violet. Very large. $\mathbf{5 . 0 0}$

87 SWEET LAVENDEP. S. lavender; F. dark purple. .35

8.1 TAT MAHAL. Beautiful, large white flower. Smooth texture. .75

88 TENEBRAE. Large flowers of rich dark coloring. 1.00

THAIS. An attractive rose mauve, which is nearly a self. 5.00

83 THESEUS. A very fine large white flower of fine substance. 3.00

82 TITAI. S. violet blue; F. violet-purple. Enormnus flowers. 1.50 
82 TROADES. S. old rose with $\mathrm{F}$. bright red violet in color.

85 TROPIC SEAS. A tall large flower of deep blue purple.

84 TRUE CHARM. A delightful white, showing blue lavender. 50

80 TUSCANY. S. bright blue. F. deep purple red.

TUSCANY GOLD. S. sulphine yellow. F. more purple in shade. 12.00

85 27th AVRIL. A violet purple, much admired. Outstanding.

1.00

88 TYRIAN. A vivid deep claret. Much admired.

UNCLE REMUS. Deep mulberry purple self. Different.

85 VALENCIA. A beautiful bright orange bluff self.

VAN CLEVE. Deep purple velvety, almost a self. Tall.

81 VELOUTE. S. deep analine blue. F. velvety black violet.

89 VESPER GOLD. Several tones of yellow, charmingly mingled.

WATTEAU. S. campanula violet. F. violet purple.

85 W. C. TERRY. S. violet blue; F bright crimson purple. $\quad .75$

87 WEDGWOOD. Deep rich shade of indelible purple.

82 WESTERN DREAM. Our best seedling of 1923. Light violet self. .50

80 WILD ROSE. Pale amarath pink.

WHITE AND GOLD. A large fine white, enhanced with a gold beard. 5.00 WHITE STAR. Another fine white of good size.

81 WHITE QUEEN. Absolutely pure white, even the beard. Early. 1.25

81 WILLIAM MOHR. Pale lilac, standards flushed darker.

85 YELLOW MOON. A beautiful yellow self, taller than most yellows. 1.00

83 YELLOWSTONE. S. straw yellow. F. velvety pansy purple.

85 YEOMAN. A fine blue velvet. Very attractive in field.

82 YOLAINDE. A beautiful blue the F. being pansy blue.

\section{INTERMEDIATE IRIS.}

These are dwarf iris and bloom two to three weeks before the bearded varieties. Very good for rockeries and embankments.

ALBICANS. Pure white throughout. Good flower.

CARTHUSIAN. Clear lavender blue. Fine quality.

DON CARLOS. S. blue. F. red purple. A different flower.

FIRMAMENT. S. deep chickory-blue. F. darker.

FRITJOF. S. lavender. F. purple. A free bloomer. .25

HELGE. Lemon yellow with pearly shading. Good color blending. .25

KOCHI. Handsome rich claret-purple.

WALHALLA. S. lavender-blue. F. violet-purple. 


\section{ANY 2 FOR 25c}

These are surplus iris which we are offering at this special price. The prices of these plants as quoted by other dealers range from $25 \mathrm{c}$ to $\$ 3.00$. Orders will be filled until supply is exhausted. Please designate second choices; otherwise we will refund money if unable to fill order as we do not substitute! Entire order must amount to $\$ 1$ including other irises. Just check varieties wanted and tear out this sheet. \$10.00 per 100 .

Afterglow, greyish-lav. Alcazar, cotinga-purple Angeio, lavender-blue Anna Farr, violet Antonia, red-purple Aragon, yellow-brown Argonaut, lavender Arsace, grey white Aurora, rosy lilac Autocrat, blue Azure, blue Asure Glow, lavender Ballaruc, white Barrelane, reddish Bellađona, white Bronze Lady, bronze Catalosa, violet Cavalier, blue Chatelet, pink-violet Cretome, maroon Col. Candelot, mauve Dainty Lady, bluff Dalila, lavender Dianto, purple Dora Longdon, magenta Dusky Maid, bluff Dawn, yellow Dorman, reddish Eckesachs, violet Eglamour, purple E!dorado, bronze Emir, blue Edith Cavall, white Fedora, old gold

Forsette, lavender

Fuerstin Lonyay, violet

Fro, gold

Gen. Gallieni, purple

Gold Crest, blue

Grevin, violet

Genghis Khan, purple

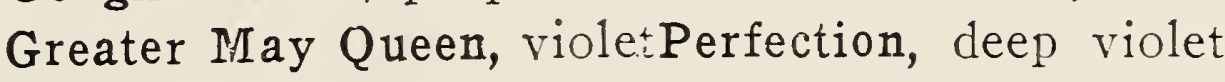

Glitter, yellow

Hackador, pink-lavender Prosper Laugier, tan

Harpalior, lavender-bronzePseudacorus, yellow water

Hussard, deep blue.

Ilsan, violet

Inca, yeliow

Jacquesiana, purple

Jassieu, pinkish

J. J. Dean, purple

Julia, blue

J. B. Dumas, light rose

Knysna, yellow brown

Lancelot, mauve.

Lohengrin, mauve

Lorely, yellow purple

Magnate, violet

Moliere, violet

Mrs. Viesseux, purple

Minnehaha, grey

Mandarin, orange red

Morwell, blue

Mesopotamica, violet

May Rose, dull rose

Mauvine, mauve

Neptune, blue

Nine Wells, violet
Oliver Perthuis, blue

Olivia, lavender-violet

Oriflamme, blue

Orchid, grey

Ophir Gold, yellow

Parc De Neuilly, violet

Pont-A-Mousson, violet

Purple Lace, purple.

Quaker Lady, bluff

Queen, blue

Raffet, purple

Regan, purple

Rheintraubs, violet

Rosedale, lavender

Ringdove lavender

Rita, blue-lavender

Ruby Queen, violet

Shalimar, blue

Sherbert, purple

Stamboul, violet

Sudan, bronze

Thecla, bright mauve

Thelma Perry, lilac

Turco, violet

Vio. Grandiflora, blue

Violetta, blue

Virginia Moore, lemon

Warrier, bronze

White Knight, white

Zilia, violet blue

Bosniamac, purple dwarf 


\section{ORDER SHEET}

WEED'S GARDENS

BEAVERTON, OREGON

Name

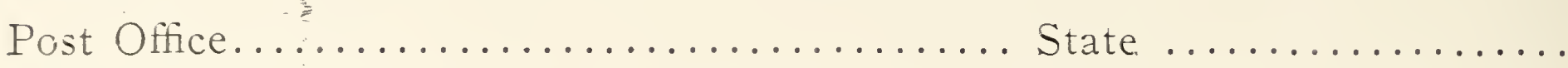

Street

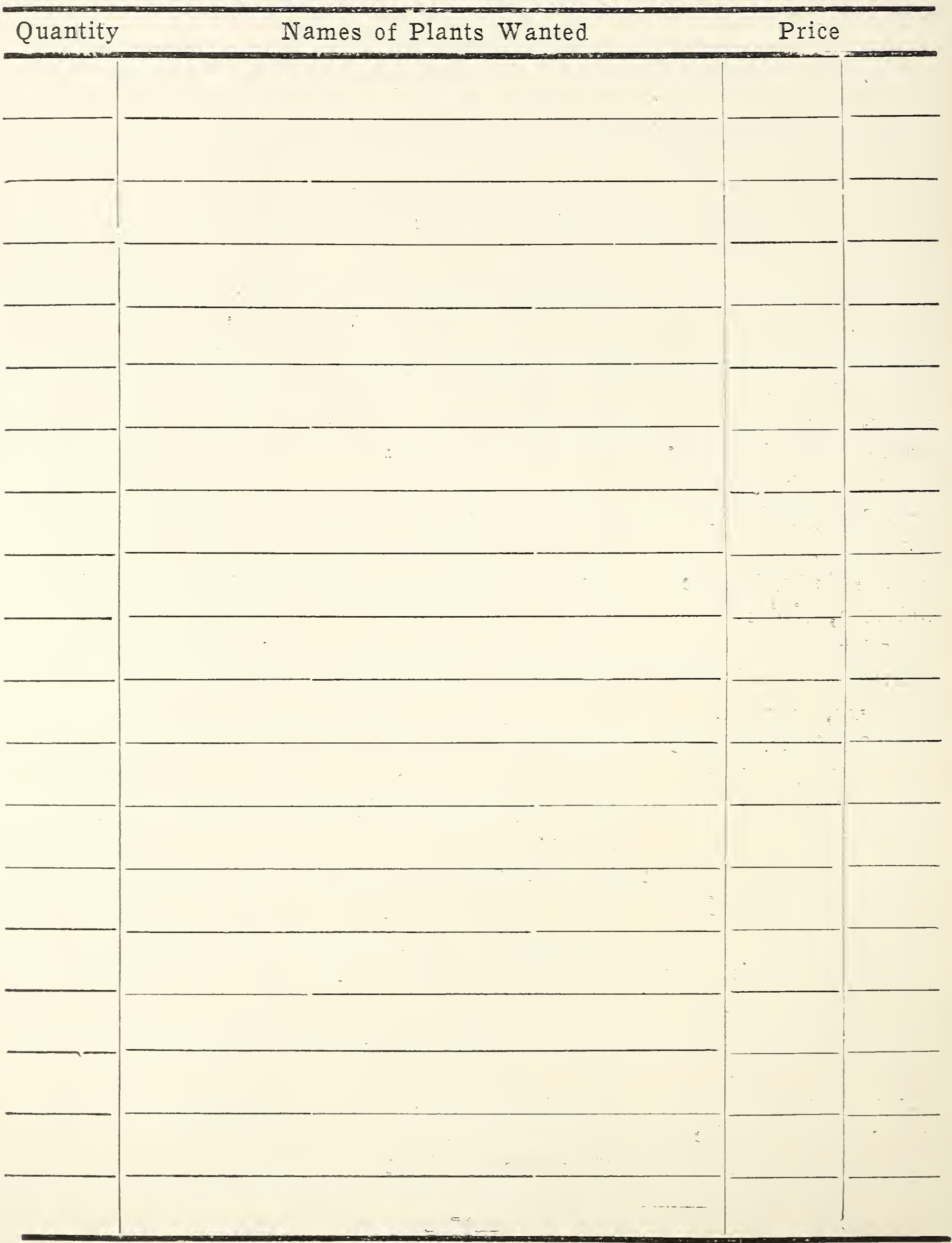




\section{OUR INTRODUCTIONS OF 1930}

This year we are introducing four Oregon seedlings of very exceptional merit. Three are out of the same seedpod - Titan on Mme. Gaudichau - but each is entirely different. These flowers have attracted marked attention for the last two years and we are now introducing them with the greatest of confidence. The price may be considered high by some, but the plants are well worth all that is asked and more. We describe them in their order of merit.

OREGON BEAUTY, Kleinsorge, 1930. A very large flower, seren inches across, the falls 2 by 4 inches. S. aconite violet; F. bright velvety cotinga purple, with strong medial line and edge brighter. Beard strongly yellow. Style branches a beautiful crome yellow except for a medial line of violet. Haft beautifully marked brown. Height 38 inches, the flowers keing borne on strong stiff stems.

OREGOIN GIANT. Kleinsorge, 1930. An immense bloom. S. 3I/2 inches long, reddish purple. F. 2 by 5 inches, widely flaring, blackish purple, very relvety. Teins at haft and style arm, deep purple. Heary gold beard, six flowers to a stalk. Height 42 inches. 50.00

KLAMATH. Kleinsorge, 1929. S. hissop riolet, F. prune purple. Style branches chalcedony yellow on sides, crest purple drab. Beard extremely yellow. Haft and claw beautifully marked with brown. Height 42 inches.

HIGH TIDE. Barber, 1930. Caterina on Asia. Entire flower soft dark lavender, of Asia type but much better and larger. S. blue lavender. $\mathrm{F}$. darker and flaring. Base of $\mathrm{F}$. light colored with a yellow edge. Height 42 inches.

This variety is a rery handsome fower, originated by the man who has produced the most beautiful Delphiniums in the world known as Hoodacres Delphiniums and grown at Troutdale, Oregon.

We will furnish one each of the four seedlings described abore for $\$ 135.00$

NEWTONIA. Donahue, 1929. Amber colored pastel self. of fine form and substance. A frosty irridescence and golden beard illuminates the entire flower. This variety has the same growing qualities as Mme. Cheri, one of its parents. It is four feet tall and well branched. We are glad to be cne of the two growers who have been selected to introduce this fine flower this year.

50.00

\section{A MONEY BACK GUARANTEE}

These five plants are as fine as any Irises ever produced. If obtained now they will make a rapid increase and can be sold at a good profit in the years to come. Any person who is dissatisfied with one of these four varietites, may return the plants at our expense after the first year blooming and we will refund the money paid with no questions asked. In this way, the purchaser will be enabled to see the true ralue of these flowers with no risk to himself. This offer does not apply to parties living within a hundred miles of. our gardens as they are expected to visit our fields in person. 


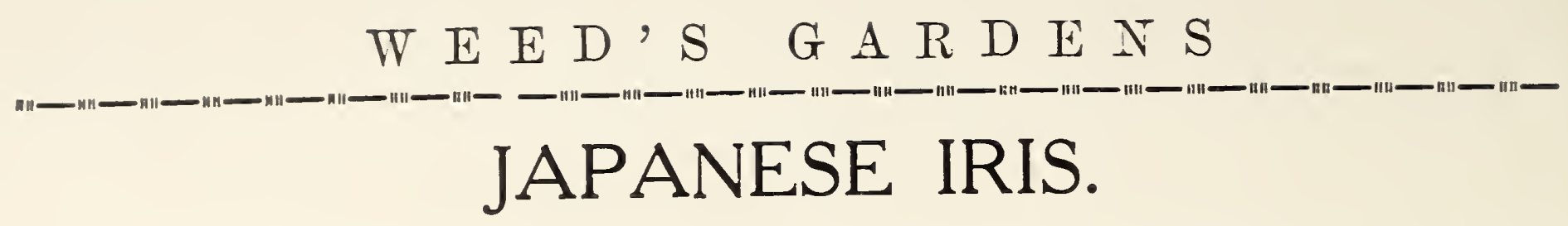

These remarkable iris are now coming into great popularity as their merits are becoming better known. They bloom after the bearded iris and continue blooming for fully six weeks. They have three, six, or nine petals known respectively as single, double, and very double in our descriptions.

Japanese iris require an acid soil to give the best bloom although they will bloom in any soil. The proper acidity is obtained by applying a small amount of sulphate of ammonia to the soil in which they are planted-a handful to each plant, applied once a year. Sheep guano is the best fertilizer but use no lime. These iris grow in practically every state, even in Minnesota. In a few places where they have not succeeded, their failure may be attributed to them being planted too late in autumn and thus being heaved out by the frost. Plant either in September-October or MarchApril. When they are ordered with bearded iris, we hold this part of the order until the proper time for planting. While they give larger flowers if well watered, the roots should not stand in water during the winter.

It is to be regretted that most dealers sell "mixed" varieties, this term being used to designate seedling's of unknown value - not one per cent of which are worth planting. We have keen perfecting our list of varieties for a number of years and have what we believe to be the best collection of named varieties in this country, if not in the world. We contributed nearly a hundred varieties to the Brooklyn Botanical Garden some years ago. Many of these varieties have been returned to us with the names which the Garden recognizes. We desire to have our Japanese Iris as correctly named as our other varieties. When other dealers are as particular, this class will become as popular as the bearded Iris now are.

\section{SINGLE.}

AYASI. White center with wide crimson edge. Best seller. 50 DOMINATOR. Handsome. Grey ground overlaid with blue. 1.09 FRANCES E. CLEVELAND. Gigantic blue lavender. Best Japanese. 2.00 HOTARI. Light lavender, veined purrle.

HIMONO. Very dark cerise. Style, branch white, crested purple. .75

HATSUKI. Uniform purple blue. Very attractive flowers.

JOSEPHINE HEYWOOD. Blue with purple sheen. .75

KAGARABI. Light lavender, veined red purple. Very good. 75

A large and handsome flower of good appearance.

KASAGA. Crimson purple, edged white.

MONIJA. A dark crimson, edged white

NISHIKI. Large crimson falls, penciled white. 75

OTOMENE. Royal purple, overlaid with lavender. Quite tall. 2.00

PARAGON. A beautiful large flower of deep purple. This variety has been greatly admired in our garden. 
SHADOW. Reddish purple.

SHIMOYO. Greyish white, veined violet.

SHORYUI. White ground shaded and overlaid purple blue.

SUIBYIN. A very beautiful dark purple, veined white.

SURI. Grey ground overaid with blue. S. purple.

TRIUMPH. Lavender, veined dark purple.

TSURO. Large pure. white of firm substance.

TUYI. Dark violet blue, flaked white.

VIOLET BEAUTY. Pansy violet, with yellow blotch. 1.00

YEDO PRIDE. Dark plum, crome yellow center. Handsome. 2.00

\section{DOUBLE.}

ANGEL'S DEN. Vinous purple. One of our best sellers.

AOIGATA. Very large reddish-lavender petals, edged light orange. 1.00

APOLLO. Lilac-blue, splashed lighter,

ASAGIRE. Variegated with white and blue.

.75

CLOUD DRESS. Grey ground with prominent purple lines .50

CLOUDY SKY. White center, tipped crimson-red. Beautiful. .50

DOJl. White, overlaid with lavender.

FIREFLY. Deep purple with golden bloæch. Last to bloom. .50

GENIIYAMA. Rich dark purple, blue halo $\mathbf{5 0}$

GOLD BOUND. A large pure white, with beautiful gold bar. $\quad .50$

HOSOKAWA. Purple-biue, white lines radiating from gold bar. .50

ISHO. Very large Hower of blue petals, white center.

ISSUIGIN. Blue lavender, white fencilings radiatirig. .75

KAMATA. Very large flower of crimson purple.

KATSURAO. Lavender, overlaid with blue around yellow blotch. 1.50

KASUGANO. Plum-purple, with dark pencillings, radiating .50

KOHIO. Light lavender ground, Mottled purple. .

KOMACHI. Very double. Deep violet-purple.

KOMBARIN. A large early pure white.

KOYKA. A very beautiful purple blue, spashed lavender. 1.00

KUMO ISHO. Bright crimson purple. Very attractive flowers. . 5

KURO KUMO. Deep purple, overlaid with blue, $\quad .50$

MARJORIE PARRY. Delicate light mauve. $\quad 1.00$

MRS. HAYDEN. White, edged and shadowed pale violet. 1.00

RINPOO. Veined and splashed pink on a white ground. .75

RISHONO. Very double. Purple, overlaid with blue. Good. .75

SAMIDARE. Pale lilac with deeper pencilings, $\quad .75$

SHIGA. Reddish blue. A large and handsome. flower. Good. $\quad .75$

SHIKARI. Claret wine, with bright orange throat. 1.50

SWORD DANCE. Very large flower of reddish maroon. 2.00

TOSEN. Light mauve, pencilled and tipped violet. 1.00

TSURIGI. Large, pure white of firm substance. 
WAIAMA. Bright crimson purple, splashed white.

WAIINIRA. Crimson violet. White halo, surrounding yellow bar 2.00

YONOMIO. Grey ground overlaid with crimson-maroon. 1.00

zUTSU. Very double. Violet-biue

These Iris are fine for planting around lily pools or in special Japanese gardens. They make an attractive showing, however, in any garden and bloom at a time when the majority of other flowers have passed. We will furnish the set of 61 varieties for forty dollars.

\section{MISCELLANEOUS IRIS.}

CACIQUE, A unique flower, being a Fulva hybrid. Prune purple. 1.00 DOROTHEA WILLIAMSON. An American hybrid of a royal purple. Entirely different from others and fine for talle bouquets. .50 PSEUDACORUS. Known as the "Yellow Water Iris." .25 PSEUDACORUS GIGANTEA. An improved form of the above. .25

\section{PALESTINE IFIS.}

These Iris are hardy and the flowers fine. They bloom two weeks: before the tall learded varieties. They must not be watered during the summer and should be planted only in the early fall. Picture on back of catalog is of a Palestine bloom.

BUCHARICA. A fine early yeillow.

CHARON. Golden-brown chocolate. $\quad 1.50$

HAMADAN. S. light violet; F. purple-violet, black beard. 1.50

HOOGIANA. A very beautiful tall lavender blue. 203

IPFALL. Deep red-violet. $\quad 1.50$

KOROLIOWI. Lilac, veined purple. Very beautiful. 1.00

ZWANENBURG. S. cream, blotched greenish bluff. F. chamois to olive brown. Vigorous flower and very early. Classed among the best fifty iris and is very easy to grow.

In order to give all an opportunity of having these beautiful flowers which bloom so much earlier than others, we will furnish one each of the above for five dollars. Include them in your order for other irises and we will send in septemter. 
ANGUSTIFOLIA. This is our Winter bloomer and is a delightful flower of a light lavender coior. The plants have grass-like foliage and bloom from the first of December until April, depending upon wcather conditions. It is not hardy in the Eastern states, except in the South.

\section{IRIS SIBERICA.}

'The iris of this group have tall stems and grasslike foliage. The flowers come in various shades of blue, with white markings. They make good cut flowers and the plants do well in wet ground, but are easily grown in any soil.

BIUE KING. Deep purplish blue. Very attracive.

BUTTERFLY. Clear porcelin blue. Makes good cut flower. $\quad .50$

EIPEROR. A large, fine deep viclet. 4 ft. Best Siberian. .50

IIRS. SANDERS. Very dark blue. Good. in bouquets.

PERIY'S BLUE. Handsome clear deep blue. of good quality. $\quad .50$

SANGUINEA. Intensely brilliant blue flowers. .25

SINOW QUEEN. Pure glistening white with yellow throat. .25

SUNNYBROOK. Large greyish blue.

SUPERBA. Tiolet-bluc. of good appearance ${ }_{25}$

\section{IRIS SPURIA.}

These Iris are generally mentioned as the Oriental iris, because of being native to various oriental countries. Many of the forms now in the trade, however, have been produced by crossing with various species. The plants are mostly five feet in height, the flowers borne on a tall istiff stem, well above the blade-iike leaves. They do well in any soil, but will stand a wet soil in which the tall bearded iris will not grow. They can thus be massed to adrantage on the border of pools or streams. They bloom in Oregon during June, much later than the bearded varieties.

AUREA. A wonderful yellow. of good size.

DOROTHY FOSTER. S. soft violet; F. light blue. $4 \mathrm{ft}$. $\quad .75$

MONNIERI. Golden yellow flowers. on tall stalks.

MONSPUR. Tarious shades of blue.

MRS. TAIT. Soft porceldin blue. Good in mass.

NOTHA. S. rich violet; $F$. blue, spotted yellow. 50

OCHROLEUCA. White, with orange blotch on falls. .25 


\section{SPECIAL BARGAINS IN PEONIES.}

Realizing that many who desire a selection of peonies may not have the time or inclination to select the proper varieties from our gardens or displays. we give below several collections which are truly bargains. They have been selected so as to give the most value for the money.

Collection No. 1-Ten peonies, giving the best flowers for the price:

Officinalis rubra ....................... .50 The Bride........................... 2.03

Felix Crousse........................... 1.00 Alexandriana ......................... 1.00

Festiva maxima ...................... .50 Edulis superba ..................... 40

Marie Lemoine ...................... .50 Golden Harvest ..................... .40

Floral Treasure .................... .40 La Rosiere ......................... .40

This collection will be furnished for $\$ 5.00$.

Collection No. 2-Ten peonies giving the best range of colors:

White, Festiva maxima.

White, Marie Lemoine.

Pink, Edulis' superba..

Pink, Crown on Crown.

Red, Felix Crousse.
.50 White, Avalanche

.40 Multicolor, Glory of Summerset .40

.40 Pink, Reine Hortense................ 3.00

.50 Red, Officinalis rubra............. .50

1.00 Red, Rachel, T ...................... .75

This collection will be furnished for $\$ 6.00$

Collection No.3-Ten peonies giving the longest season of bloom:

Very early red, officinalis rubra .50 Early white Festiva maxima .. .50

Early pink, Edulis superba ..... .40 Early red, Bertha ................. 40

Midseason white, La Rosiere ... .40 Midseason pink, Crown on Crown .40

Midseason red, Rachel, T....... .75 Late white, Marie Lemoine.. .... . .50

Late pink, M1le. Leonie Calot ... .50 Late red. Grover Cleveland .... 1.00

This collection will be furnished for $\$ 4.00$. 


\section{PEONIES.}

Our specialization in Peonies began in 1912 with the purchase of the largest collection then in the west and its removal to Beaverton. There are 374 varieties described in this catalog - far too many we admit and so we have made the prices extremely low in order to reduce the number of varieties during the coming year. If you will compare these prices, with the prices of other dealsr, ycu will realize just how low they are. Also bear in mind that we prepay postage and make prompt shipment after the middle of September, which is as early as a peony should be moved. We have shipped to all parts of the United States with satisfactory results.

Our peonies begin flowering in early May and continue during June. If you have never seen them in bloom, mere words cannot describe their beauty to you for they make a two acre bouquet of pink, white and red with all the various shades between. Last year we had 20,000 visitors and we trust that you will be one of that number to visit our gardens this year. We give a large well balanced root of 3 to 5' eyes, having been grown in rich clay soil. Anyone dissatisfied with plants they receive from us may have their money refunded with the-return of unsatisfactory roots.

\section{CULTURAL DIRECTIONS.}

Plant in ordinary soil, first spading the ground well and then planting so that the eyes will be covered with two inches of dirt. Too deep planting results in blind shoots, while exposed eyes result in weak flowers. Flant in full sunlight, away from the roots of trees or shrubs.

Do not fertilize with barn yard manure or other fetilizer rich in nitrogen. Peonies need acid phosphate to produce flowers and potash in order to give strength to the stems. Bone meal is the ideal fertilizer for this purpose. Apply in the fall or early spring for the ingredients are not immediatedly available for plant food. Scatter the fertilizer around each plant - about a handful to a plant - before the working of the soil each year. The dirt arcuind the plants should be kept well stirred in order to retain the soul moisture.

\section{PEONIES AS CUT FLOWERS.}

Peonies will last as cut flowers from a few hours to two weeks. When cut in the field after being fully open and especially when cut in the middle of the day, they last but two to three hours. But cut in bud early in the morning or late in the evening and then placed in water in a cool place, the blooms will last for several days. We keep the Reine Hortense variety two weeks in this way. 
OFFICINALIS RUBRA PLENA. Th:s is the old fashioned early red. .50

\section{SINGLE PEONIES.}

The single varieties are becoming very popular as they become better known. They are more early in season and very attractive.

85 BLACK PRINCE. Th. Dark sarnct, not glossy.

73 CAMITLE. Des. A prirple flower of good appearance.

CATHERINE FOX, Ber. Berutiful deep rose pink.

CELESTE BROCHET, Bro, Fine soft flesi pink,

CELESTIAL, Barr. Very tali, dark pink.

DOG ROSE, Wal. Bright rose pink.

DREADNOUGHT, Barr. Brillint crimsnn.

81 EGLANTINE, Des. White, tinged cainine.

FINE LADY, Kel. Blush-white, cup-shapel flower.

HESPERUS, Kel. Clear pink. Very good.

81 LA FRAICHEUR, Des. Rosy-white.

86 LE JOUR, Shay. Very large white.

84 L'ETINCELANTE, Des: Brilliant carmine

77 LUCIENNE, Des. White, slightly tinged purple. 1.00

82 MAFEKING, Kel. Bright scarlet crimson:

85 MADELAINE GAUTHIER, Des. Silvery flesh-pink.

85 MARGUERITE DESSERT, Des. Fine pure. white, splashed carmine. 3.00

78 METEOR, Kel. Bright dazzling crimson.

74 MILliAs, Kel. Dark crimscn.

86 NELLIE, Kel. Fine waxy shell pink.

NULII SECUNDAS, Kel. Deep crimson scarlet.

NYMPHE, Des. A large flesh pink.

OPHIR. Deep crimson on tall stems.

OTHELLO, Des. Clear carmine changing to purple. 2.00

PERLE ROSE, Des: Clear china pink, silver border. 3.00

84 PERLE BLANCHE, Des. Pure white.

59 PPIDE OF LAINGPORT, Kel. Peach pink.

PURE LOVE, Kel. A beautiful shell pink.

PURITY, Kel. A good white flower.

85 ROSY DAWIN, Barr. White resembling a water lily 2.03

SILVER CUP, Kel. A white flower.

78 STANTEY, Kel. Brilliant dark crimson.

84 THE BRIDE. A very light flower of fine substance. - 2.00

78 THE MOOR, Barr. Purple garnet.

73 VELOUTINE, Des. Tyrian purple, velvety reflex.

76 VESUVE A good dark red. 


\section{JAPANESE PEONIES.}

These have two rows of guard petals, with stamens transformed into narrow petaloids without pollen. The flowers are entirely different from the double varieties.

81 AKALU. Guard petals carmine, with saffron-yellow center. 2.05

ALBATROSS, Wal. Pink tinted, with old gold center. 3.00

85 ALMA, Sh. Pale pink guards, enclosing yellow petaloids. 1.50

-2 AMA-NO-SODE. Rose pink. Best Japanese of its color. $\quad 0.00$

82 ATtRaCtion, Hol. Guards deep tyrian rose, center tipped yellow. 1.00

AUREOLE, Hol. Guards pink, with golden yellow center. 2.00

77 BEACON LIGHT, Wet. Carmine. Very beautiful. 1.50

C.AT.YPSO, And.. Amaranth pink in color. 4.00

CASCADE. Pure white, resembling a water-lily. $\quad 1.00$

82 CATHEDRAL. Guards maroon, center lighter. 1.00

CRIMSON AND GOLD, Wal. Crimson, center flushed old rose. 3.00

CRYSTAL QUEEN. A large, handsome, pure white. 1.00

DAWN, Wal. Soft pink, center cushion of straw stamenoides. $\quad 5.00$

85 DEPARTING SUN. Rich crimson, center rose and yeslow. 3.0 J

DRAGON'S HEAD. Pale, striped crimson with yellow center. 1.00

EILEEN KELWAY, Kel. White, long narrow petaloids: 1.00

FELICITY. White, yellow petaloids. 3.00

85 FLAMBOYANT. Rose, with yellow center. 2.00

82 FLASHLIGHT, Hol. lyrian rose, center amber yellow. 2.00

79 FUJIIIINE. White, center tipped yellow. 4.03

92 FUYAJO. Rich maroon, center striped crimson and yellow. 6.0 ?

77 GEORGETTE, Wet. Violaceous pink. 2.00

GERALDINE, Kel. Deep carmine violet. 1.00

74 GOLDEN NUGGET, P1. Rosy lilac, center orange yellow. $\quad 2.00$

82 GOLDMINE, Hol. Purple-1ilac, center deep yellow. 2.00

77 HO GIOKU. Pure white, with sulphur yellow petaloids. 4.00

IMPERIAL QUEEN, Wal. Bright crimson, petaloids sellow, 4.00

83 INNOCENCE, Hol. Lilac-rose, petaloids canary yellow. 2.00

86 KING OF ENGLAND, Kel. Rich ruby madder. , 5.00

KUMAGOE. Deep carmine pink, striated with white. 1.00

76 LOBOLAS. Dark crimson;, petaloids tipped yellow. 1.00

LOTHARIO. Wet. Lavender pink. Good. 2.00

85 MIKADO, Barr. Dark crimson, petaloids crimson 11.50

NEPTUNE. Shell pink. A fine flower. $\quad 1.00$

NOONDAY, Kel. Rose, very fine. $\quad 5.00$

82 OHIRAMA. Carmine, slightly tinged purple. 3.00

OLIVIA. Lilac-white, petaloids amber-yellow. 3.00

ORANGE PRINCE, P1. Deep rose, petaloids orange. 1.00 
PURITY, Wal. Pure white, petaloids lemon.

77 QUEEN ALEXANDRA, Wa1. Soft pink, petaloids amber.

3.00

ROSALIND. Pink, petaloids tipped bluff.

2.00

SATTRN. A fine rosv white.

82 SEIRU SOMAE. Milk-white, petaloids sulphur-white.

2.00

2.00

SHAVANO. And. Amaranth pink.

2.50

SNOWDRIFT, Wal. Pure, white, canary yellow center. 2.00

82 SNOW WHELL. Immaculate white, yellow center.

3.00

90 SOME GANOKO. Very dark red. Highly recommended.

5.00

83 SUNBEAM, Hol. Pale rose pink, center cream yellow.

SUNRISE. Crimson, petaloids tipped yellow.

TAKADORAMA. Satin-white, semi-double.

1.00

1.00

1.00

94 TAMATE-BOKU. Considered the finest of all Japs. Ours is the

true variety and different from others in Oregon. China pink. 2000

TATSUGASHIRA. Striped pink, red center. 4.00

THE DRAGON, Wal. Brilliant crimson. 3.00

TITIAN. Soft lilac-pink, with yellow stamenoides. 2.00

TOKIO. Rose pink, similar to Tamate-Boku. Very good. 4.C.)

VESTUCIUS. Pale lilac-rose, narrow stamenoides. 1.00

WHITE QUEEN. A very good white. 1.50

85 WHITE SWAN, Pl. Magnolia-white. $\quad 4.00$

\section{DOUBLE FLOWERING PEONIES.}

76 ADELAIDE HOLIIS, Hol. Large, compact, globular crown. $\quad 3.00$

88 ADDIELANCHEA, Br. Creamy white. Very fine. Rose type. 3.00

$85 *$ ADOLPHE ROUSSEAU, D. and M. Semi-double. Purple garnet. 3.00

86 ALBERT CROUSSE, C.r. Shell pink, center flecked crimson. 1.00

71 ALEXANDRIANA, Ca1. Large, full double rose type. - 1.00

87 ALBATRE, Cr. Blush white of waxy texture. $\quad .75$

88 ALSACE LORRAINE, Lem. Large, flat semi-rose type. ' 1.00

86 A. P. SAUNDERS, Th. Flesh white, with nearly pure white center. 5.00

81 ARLEQUIN, Des. Guards purplish pink. Center salmon pink. 2,50

81 ASA GRAY, Cr. Guards flesh, center lilac. Very fine. .50

80 ASSMANSHAUSEN, G. \& K. Flat rose type. Pure white. Late 2.00

87 AUGUSTE DESSERT, Des. Crimson carmine with silky reflex. $\quad 4.00$

80 AURORE, Des. Flat, crimson and showing yellow stamens. $\quad 1.50$

87 AVALANCHE, Cr. Milk white, center tinged lilac. Attractive. .40

80 AVIATEUR REYMOND, Des. Bright cherry red. Exquisite. $\quad 1.00$

88 BALL O'COTTON, Fr. Rose type. Pure white. 6.00

90 *BARONESS SCHROEDER, Kel. Large, globular, rose type. .50

85 BAYADERE, Lem. Water-lily effect with golden stamens: 2.00

79 BEAUTY'S MASK, Hol. Bluish white, tinted lilac, 1.00

BERTHA. A very fine red. Best inexpensive red. $\quad .40$ 
86 BERTRADE, Lem. Compact, globular, rose type., Irory white. 2.00 89 BETIY BLOSSOII, Th. White guards. Extreme center yellow. 10.00 80 BOULE DE NEICE, Cal. Snow white, flocked crimson. Tall grower. .40 E2 BRAND'S MAGNIFICENT, Br. Deep red, shaded with blue. 3.00

73 B TNETE HILL, Hol. Tyrian rose in color.

84. CANDEUR, Des. Silvery pink, tinged lilac-rose,

85 CHARLES NEIDEL, Wet. Soft blush pink, flushed darker. $\quad 2.00$

78 CEARLES McKELIIP, Br. Crown type. Rich crimson. 1.50

84 CHESTINE GOWDY, Br. Crown type. Shell pink, 1.00

87 CLAIRE DUBOIS, Cal. violet rose, tipped silvery white. 1.00

85 CLEMENCEAU, Des. Carmine, shaded amaranth. 2.00

91 COPIELIA SHAYIOR, Sh. An extra fine pink variety. 10.00

85 COEONATION, Kel. Guards light pink, center cream-flesh. $\quad 3.00$

81 COUEONIE D:OR, Cal. White, with a ring of yellow stamens. $\quad .50$ CROWN OIN CPOWN. Three layers of pink petals. Odd. 40

C. W. SHOCK, Fr. Rose type. An unusual shade of red. $\quad 1.00$

84 DAVID HARUM, Br. Bright red. 2.00

77 DORCHESTER. Rich, large, full flower of rose type. 1.50

91 DORIs, Shay. Cup shaded. Fresh pink. Free bløomer. 600

DR. H. VAN DER TAK, Nieu. Semi-rose. Wine red. 1.00

78 DUC DE WELIINGSON, Cal. White guards, sulphur center. .40

81 DUCHESSE DE NETOURS, Cal. White, sulphur white collar. 40

91 EDWIN C. SHAW, Th. Clear rose, slighter at tips of petals. 15.00 EDITH FORPEST, Hol. Bright pink, a very free bloomer. 4.00

82 FDMOND ABOUT, $\mathrm{Cr}$. Shell pink, deecer at center. 2.00

83 EDMOND LEBON, Cal. Rose.type, bright violet-rose. 2.00

87 E. J. SHAYLOR, Sh. Clear silvery pink of globular shape. $\quad 5.00$

76 EDULIS SUPERBA, Lem. Crown type. Fine pink. Early. .40

78 E. G. HILI, Lem. Semi-rose type. Uniform tyrian rose, early. 2.00

92 F. B BFOWNING. Br. White, guards and center marked crimson. 250

87 ELWOOD PLEAS, P1. Light rose shading to lilac 1.50

EMMA LEWIS, Lew. Rose type, fine clear pink. 3.00

81 EMILE HOSTE. Snow white, flecked crimson 50

89 ENCHANTRESSE, Lem. Creamy white, flecked crimson. $\quad 3.00$

79 ESTAFETTE, Des. Clear purple, carmine reflex. 1.00

77 ESTHER, Terry. cream, tipped with light rose. 1.03

ENTENTE CORDIAI, Riv. Semi-rose type. Fine light pink. 1.00

80 ETTA, T. Flat, rose type. Shell pink. Very late. 1.00

82 EUGENE BIGOT, Des. Semi-rose. Brilliant red, silver tipped, late 1.00

83 EUGENE VERDIER, Cal. Rose type. Late. Hydrangea pink, 1.00

86 EUGENE VERDIER, Cal. Flat; semi-rose type. Shell pink. .50

89 EUNICE SHAYLOR, Sh. Globular blooms of ivory white. 3.00

81 EUPHEMIA, Ter. Lilac rose flowers. 1.00 
81 EVENING GLOW, Hol. Large. Hydrangea pink, tipped white. 1.00

82 EVANGELINE, Lem. Pale lilac rose, splashed scarlet. 1.50

76 EXPO. UNIVERSALLE, Cal. Violet rose with silvery reflex. .50

85 EXQUISITE, Kel. Semi-rose. Deep rose pink. 2.00

78 FARIBAULT, Br. Compact, rose type. Deep rose, silvery sheen. 1.00

84 FELIX CROUSSE, Cr. Typical bomb. Brilliant red. 1.00

93 FESTIVA MAXIMA, Meil. White, crimson markings in center. $\quad .50$

75 FLORAL TREASURE. Rose type. Pale lilac-rose. 40

78 FLORENCE NIGHTENGALE, Br. White, edged crimson. .50

89 FLOWRET OF EDEN, Neeley. A magnificent silvery pink. 5.00

82 FRAICHEUR, Lem. Creamy white, pink at edge. 1.50

86 FRANCES SHAYLOR, Sh Gistening white, golden staminoides. 2.00

91 FRANCES WILLARD, Br. One of the best whites. 2.00

81 GALATHEE, Lem. Rose type. Fleshy white. Late. 1.00

89 GEORGIANA SHAYLOR, Sh. rose pink, splashed crimson. 3.00

85 GERMAINE BIGOT, Des. Pale lilac-rose, center crimson. $\quad 1.00$

83 GIGANTEA, Cal. Pale lilac rose, darker center. 1.00

82 GISMONDA, Cr. Flesh color, delicate rose center. 1.00

GLORIA PATRIA, Foul. Fink, shaded violet. High crown. 1.00

79 GLORY OF SOMMERSET, Kel. Viclet rose, collar cream white. $\quad .50$

86 GOLDEN DAWN, Gumm. White petals, yellow center. 2.50

79 GOLDEN HARVEST, Ros. Guards pale lilac, center creamy white. .40

92 GRACF. TONMIS, Sa11n. A very fine late white. 10.03

88 GRANDIFLORA, Rich. Flat, rose type. U:iiform rose-white, late. 1.0J

21 GRANDIFLORA NIVEA PLEINA, Lem. An early milk white. .50

82 GROVER CLEVELAND. Compact rose type. Dark crimson, late. 1.00

82 H. A. HAGEN, Rich. Uniform deep violet-rose. 1.50

HELENA LESLIE, Birr. White, primrose center. 1.00

79 HELEN WOLAVER, Br. Rose type. Deep shell-pink. 1.00

88 HENRY AVERY, Br. Rose type. Creamy white, yellow center. 2.50

81 HERCULES, T. Semi-rose. Soft shell-pink, shaded white. .50

HESPANOLA, And. Deep uniform shell-pink, shaded deeper. 3.00

$78 \mathrm{H}$. F. REDDICK, Br. Semi-rose type. Brilliant dark crimson. 1.00

83 ISOLENE, Lem. Cream with yellow tuft. 2.00

89 JAMES BOYD, Th. Flesh, changing to nearly white, $\quad 2.00$

87 JAMES KELWAY, Kel. Rosy-white to milk white. $\quad 1.00$

87 JAMES R. MANN. Th. Deep rose pink. Very pretty. 6.00

83 JEANNE GAUDICHAU, Mil. White, edged carmine. 1.00

92 JEANNOT, Des. Flesh pink, tinged purple, 3.00

86 JESSIE SHAYLOR, Sh. Deep cream, with golden lights. 3.00

93 JOHN M. GOOD, Welsh. One of the best varieties. White. 10.0 ?

81 JOHN RICHARDSON, Rich. Pale lilac rsoe. Compact and flat. .75

89 JUBILEE, Pl. Compact, rose type. Pure ivory white. 1.00 
86 JUDGE BERRY, Br. Flat, semi-rose type. Soft pink.

88 KARL ROSENFIELD, Rose. Brilliant velvety crimson.

98 KELWAY'S GLORIOUS. Rated second best of all whites.

88 KELWAY'S QUEEN. Uniform mauve-rose. Very beautiful KONIGSWINTER, G. \& H. Soft lilac, silvery shading.

91 LADY DUFF, Kel. Semi-rose type. Pale rose to rosy white.

82 LADY BERESFORD, Kel. Large flowers of soft blush pink.

LADY DERBY, Kel. Very large pure white,

2.00

79 LADY IRIS, P1. Rose type, White, suffused with lake.

78 LAFAYETTE, Des. Rose type. Dark carmine purple.

1.00

92 LA FEE, Lem. Mauve-rose, collar creamy white. Early.

1.00

5.00

75 LA FIANCEE, Lem. Pure white, center flecked crimson.

2.00

84 LA FONTAINE, Lem. Violet-rose, center flecked red.

1.00

90 LA FRANCE, Lem. Compact, globular, rose type.

2.00

85 LA LORRAINE, Lem. Globular, bomb type. Creamy white.

2.00

84 LAMARTINE, Lem. Carmine-rose, bordered white. Late.

2.00

85 LA PERLE, Cr. Light pink, blush center.

83 LA ROSIERE, Cr. Pure white, shading to cream center.

81 LA TENDRESSE, Cr. Milk-wiite. slightly splashed crimson.

88 LAURA DESSERT, Des. Creamy white, canary yellow center.

99 LE CYGNE, Lem. White, a few yellow stamens in center.

LE MOINE LEWIS, Lew. full double. Clear pink.

LILLIAN GUMM, G. Shell-pink, deeper center.

10.03

2.00

2.50

81 LIVINGSTONE, Cr. lilac-rose. center petals flecked crimson.

90 LONGFELLOW, Br. Bright crimson, with a cherry tone.

84 LORA DEXHEIMER, Br. Intense crimson, darker at base.

2.00

72 LOTTIE COLLINS, Barr. A double red flower.

LOUIS PAILLET, Bro. Carmine rose, with silvery reflections. 2.00

69 LOUIS VAN HOUTTE, CaI. Bright réd. A great favorite

88 LOVELINESS, Hol. Light shell-pink, fading to lilac-white.

1.50

86 LUCY DUNN, Wet. A lorely pink much admired.

81 LUCY E. HOLLIS, Hol. Violet white, center pale lilac-rose.

87 LUETTA PFEIFFER, Br. Semi-double. Pinkish white.

90 MABEL L. FRANKLIN, Fr. Light pink, shading darker

86 MME. AUGUSTE DESSERT, Des. Rose pink, llecked crimson.

78 MME. BARILLET DESCHAMPS, Cal." Clear vislet-rcse.

81 MME. CALOT, Miel. Rose type. Shell-pink, darker center.

79 MME. CROUSSE, Cr. White, center flecked crimson.

82 MME. DE TREYERAN, Des. Rose white, flecked crimson.

79 MME. DE VERNEVILLE, Cr. white, carmine flecks.

89 MME. EMILIE LEMOINE, Lem. semi-rose. Milk-white. 
77 MIME. GUYOT, Pail. Crown type. Greenish whic.

79 MME. JOANNE SALLIER, Pail. Violet-rose, flecked crimson. .75

83 MME. JULES CALOT, Cal. Dwarf, rose type. Lilac-white, .50

94 MME. JULES DESSERT, Des: White, shaded buff and salmon. 1.50

85 MME. MANCHET, Des. S'lvery lilac, shaded pink at base. $\quad 1.00$

73 MME. MECHIN, Mech. Semi-rose type. Deep crimson garnet. .50

77 MME. SAVREAU, Sav. Lilac-white, cream yellow center. 1.00

82 MLLE. JEANNE RIVOIRE, Riv. rose, with sulphur-white center. 1.00

81 MLLE. LEONIE CALOT, Cal. Rose type, salmon-pink. MAGNIFICA. White with yellowish center $\quad .40$

MAIITOU, And. Cameo-pink, bleaching to rose white. 2.0J

86 MARCHIONESS OF LANSDOWNE, Kel. Shell-pink. 2.00

82 MARCELIE DESSERT, Des. Milk-white, splashed carinine. $\quad 1.00$

91 MARGARET VIERERIIER. Uniform salmon pink. 250

81 MARGUERITE GAUDICHAU, Mil. White, suffused pink. 1.00

84 MARGUERITE GERARD, Cr. Flesh pink, fading to white. .75

81 MARIE, Cal. Flat, Lilac-white, fading to milk-white. Late. 1.00

89 MARIE CROUSSE, Cr. Globular, bomb type. Pale lilac-rose. $\quad .75$

80 MARIE DEROUX, Cr. lilac-rose, with salmon shades.

83 *MARIE JACQUIN, Ver. Rose white, incurved petals,

85 *MARIE LEMOINE, Cal. Pure white, cream-white center, $\quad .50$

91 MARTIIA BüLOÕ, Br. Very fine deep pink. Late. 3.00

81 MARTEA A.TWYMAN, Wet. A very good pink. Tall. 1.00

82 IAPTHA V. T,ANE, Wet. White. Attractive flower. 1.50

79 IMARY A. LIVERIMORE, Hol. Soft shell-pink, shaded white. 1.00

87 MARY BRAND, Br. Rose type. Deep red. 2.00

87 MARY P. KING, Fr. Light coral pink, 1 n

90 IVIRY W. SHAYLOR, Sh. shell pink, center creamy yellow 2.00

79 MATILDE DE ROSENECK, Cr. rose, center deep carmine. 1.00

85 MAUD L. RICHARDSON, Hol. Pale lilac-rose. lighter center. $\quad 1.00$

90 MILTON HILL, Rich. Pale lilac-rose. Late. 1.50

77 MIREILLE, Cr. Milk-white, center edged crimson. Late. 1.00

78 MISS SALWAY, Kel. Lilac-white, collar lighter. 2.00

78 *MODELE DE PERFECTION, Cr. Light violet-rose, $\quad 1.00$

79 MODESTE GUERIN. Guer. Deop and lustrous pink. 1.00

85 MONSIEUR DUPONT, Cal. Milk-white, splashed crimson. 50

92 MONS. JULES ELIE, Cr. Deep shell-pink, 1.00

88 MINS. MARTIN CAHUZAC, Des. Dark purple garnet, 2.00

26 MONT BLANC. I em. White, center slightly rose tinted. 2.00

82 MOSES HULL, Br. Dark shell-pink. $\quad 1.00$

MOUNTEBANK, Kel. Milk-white, center amber-yellow. $\quad 1.00$ 
83 MRS. A. G. RUGGLES, Br. Flat, rose type. Lilac-white, $\quad 1.50$ MRS. CHARLES GILBERT, Sh. large flower of shell-pink. 1.50

93 MRS. EDWARD HARDING, Sh. Large white. First $\$ 100$ peony. $\quad 6.00$

83 MRS. GEORGE BUNYAND, Kel. Shell pink changing to deep bush. 2.00

79 MRS. JENNIE GOWDY, Br. Pinkish white, splashed crimson. 2.00

82 MRS. JOHN M. LEWIS, Lew. Dark red, velvety shading. 2.00

84 MRS. J. S. FUGG, Hol. Lighit pink, collar white. 1.50

83 MRS. M. P. CLOUGH, Sh. Saimon-pnk. 1.50

84 MRS. E. J. SHAYLOR. Sh. Large flower of delicate pink. 15.00

91 MRS. SHAYLOR-FODCE. Sh. I.arep ivory white. 8.00 NELL SHAYLOR. Sh. large shell pink flowers. ... 8.00

90 NINA SECOR, Secor. Pure white with yellow glow. 4.00

88 NYMPHAEA, Th. Flat, semi-rose iype. Delicate creany white. 3.00

85 OCTAVIE DEMAY, Cal. Palt pink. collar almost white. 1.00

74 OLD SILVER TIP, Br. Semi-rose. Soft madder-red, silver reflex. 1.00

85 OPAL, P1. Rose type. Guards pink, center opal pink. 1.50 OTHELLO, Lem. Deep crimson, purplish bronze shading. 2.00

82 PALLAS, T. Flat, semi-double. Light pink, shading to white. 2.00

84 PASTEUR, Cr. Rose type. Soft pink, almost white, 1.00

80 PERFECTION, Rich. Rose type. Shell-pink. Late. $\mathbf{7 5}$

92 PHILIPPE RIVIORE, Riv. Very darł crimson. Early. 6.00

77 PHILOMELE, Cal. Near yellow, fading to cream. .50

88 PHOEBE CAREY, Br. Soft lavender-pink, center darker. Late. 2.00

co PHYLLIS KELWAY, Kel. Pale lavender-pink, 2.00

82 PIERRE DUCHARTRE, Cr. rose type. Lilac-pink. Late. 1.00 POETE FREDERICK IISTRAL, Riv. Bright rose, center salmon. 2.00 PONEMAH, Fr. Pink, shading lighter at edge 1.50

83 PRESIDENT ROOSEVELT, War. Deep brilliant red. 1.00

93 PRESIDENT WILSON, Th. Soft rose-pink, Late. 15.00

89 PRIDE OF ESSEX, Th. Broad petals of deep flesh-pink. 2.00

86 PRIDE OF PAULDING, Neeley. Beautiful flesh pink. 6.00

83 POTTSI AI.BA. Buyck. Beautiful light pink. 1.00

86 PRIMEVERE, Lem. Flat, bomb type. Sulphur-white. 1.50

76 PRINCESS OF WALES, Kel. Pale lilac-rose, 1.50

83 RACHEL, Lem. Lively soft pink, darker when first opening. 1.50

79 RACHEL, T. Bright garnet-red, shaded ruby-red.

85 RALPH, P1. type, late. A large flat flower of light pink. $\quad 2.00$

90 RAOUL DESSERT, Mech. Clear mauve, shaded carmine pink, $\quad 4.00$

87 REINE HORTENSE, Cal. Very large flower of uniform hydrangea pink. This variety is the best keeper of all. Vary good. 3.00 RENEE MARIE, Des. Soft flesh pink, flecked carmine. $\quad 2.00$ 
88 RICHARD CARVEL, Br. Globular bomb. Bright crimson. Early. 3.00

90 ROSA BONHEUR, Des. flesh pink; guards flecked crimson. $\quad 2.50$ ROSE STANDISH; Hol. Very full and compact. Dark pink, 2.00 89 ROSETTE, Des. Silvery flesh, border flecked crimson. $\quad 3.00$ 76 ROSY DAWN, Pl. Anemone type, Light pink.

79 RUTH BRAND, Br. Soft lavender pink, shaded darker. $\quad 1.00$

90 SARAH BERNHARDT, Lem. Mauve rose, silver tipped. Late. 2.00

85 SARAH CARSTENSON, T. hydrangea pink, center carmine. 2.00

91 SARAH K. THURLOW. Th. Guard petals of soft blush. 10.00 SARAH WETTENGEL, Wet. A beautiint white binsh. 2.00

86 SECRETARY FEWKES, Sh. Creamy white, with lighter center. 3.00

85 SHAYLOR'S DREAM, Sh. Fine, white, semi-double, 2.50

97 SOLANCE, Lem. Lilac-white, shaded apricot-salmon. Late. $\quad 3.50$

76 SOLFATARE, Cal. Milk-white guards, sulphur collar, $\quad .50$

78 SOUVENIR DE FRANCOIS RUITTON, Bright cherry pink, $\quad 2.00$ SOUV. DU GEN. GALIENNI, Riv. Lilac-pink. 2.00

83 SPLENDIDA, Kel. Cup-shaped bomb. Light violaceous pink. 1.00

85 STANDARD BEARER, Hol. bomb. Light violet-rose. " 2.50

80 STANLEY, Cr. Compact, Light violet-rose, silver reflex. $\quad 1.00$

80 STEPHANIE, T. delicate pink, shading to whitecenter. 1.50

78 SUMMER DAY, Kel. Flat, rose type. Creamy white, tinged blush. 1.00

73 SUPREME, Hol. A light pink flewer. $\quad .40$

82 SUZETTE, Des. Fine flower of bengal-rose, tinted carmine. $\quad 1.50$

98 THERESE, Des. World's best soft pink. Lilac white ceter. 2.00

91 THOMAS C. THURLOW. Th. Salmon-flesh, changing to white 15.00

94 TOURANGELLE, Des. Flesh-pink and salmon, late. 2.50

83 VENUS, Kel. Pale, old rose pink. Very distinct.

83 VICTOR HUGO. A very good brilliant crimson.

82 VICTORIE DE LA MARNE, Des, amaranth-red, silvery reflex. 2.50

76 VIRGINIE, Cal. A good light pink flower.

93 WALTER FAXON, Rich, Bright rose, center darker. 3.03

78 WELCOME GUEST, Holl. Rose type. Semi-double. Uniform rose. .50

88 W. F. CHRISTMAN, Fr. Rose type. Flesh-pink. 2.50

22 WIESBADEN, G \& $\mathbb{K}$. Light rose intermingled with golden stamens. 1.50

84 WM. F. TURNER, Sh. Dark, velvety crimson. 3.00

79 WM. PENN, Br. Semi-rose type. Light rose. 3.00

88 WILTON LOCKWOOD, Sh. Deep pink, with crimson markings. 2.50

83 WINNEFRED DOMME, Br. Bomb type. Uniform bright crimson. 1.00

80 WINNEKENNI, Th. A beautiful late cherry pink. 1.50 

